\title{
Transport and logistics infrastructure of the Krasnodar Krai: problems and solutions
}

\author{
Anna Davydovich ${ }^{1, *}$, Aida Karamova $^{1}$, Olesya Fesenko ${ }^{1}$, Nina Anisimova ${ }^{1}$ \\ ${ }^{1}$ Sochi State University, 94, Plastunskaya str., 354000, Sochi, Russia
}

\begin{abstract}
The paper presents the role of the transport and logistics network in the economics of the Krasnodar krai. There is given a detailed characteristics of the modes of transport-logistics network: waterborne and air transport, rail infrastructure, road transportation system and logistics complex. Key issues are identified and vectors for the development of the transport and logistics network of the Krasnodar krai are set. This paper focuses on the analyses of the current state of the waterborne and air transport, rail infrastructure, road and logistics networks of the Krasnodar krai. The core issues are to sort out what hinder the growth of main modes of the transport infrastructure. The analysis is based on the officially confirmed macroeconomic parameters of social-economic development of the region. The resources under study contained information on the organizational, economic and institutional mechanisms of the interaction of economic entities of the sea and air transport, rail infrastructure, road and logistics networks. The obtained results can facilitate strategies and initiatives for the growth of the transport and logistics infrastructure of the Krasnodar krai.
\end{abstract}

\section{Introduction}

Transport and logistics infrastructure plays an important party in the social and economic development of the Krasnodar krai. It creates the necessary conditions for the economic growth of the region, the development of its competitive advantages in terms of executing the transit potential and improving the life quality of the population.

The role and importance of the transport and logistics infrastructure in the economy of the Krasnodar krai is represented by such important indicators which characterize the socioeconomic situation of the region in 2018 as: the amount of tax revenues to the consolidated budget of the region amounted to 23.13 billion roubles .; the share of transport and logistics services in the gross regional product is about $18.9 \%$, a significant share of the industry in the structure of fixed assets is $27 \%$, investments in the development of industries are $10.4 \%$; the number of employees is more than 100 thousand people; consumption of energy and metal and other indicators. [1] Thus, the transport and logistics infrastructure is closely related to all elements of the economy and social sphere of the Krasnodar krai.

In recent years, a partial modernization was carried out in the transport and logistics infrastructure of the region. It allowed to meet the growing demand for passenger and cargo

* Corresponding author: davyanna@yandex.ru 
transportation and plant the seed for further development. For example: in 2018, 29563.4 million roubles were allocated only to implement the "Development of road network of the Krasnodar krai" program, and in 2019 - 31702.4 million roubles. [2]

The Krasnodar krai has all modern modes of transport. Its distribution and structure generally meet the internal and external transport and economic relations of the region. However, there are significant setbacks to economic growth due to insufficient development of the transport and logistics infrastructure:

$\checkmark$ development of ports and adjoining railway, road and pipeline infrastructure, as well as logistic terminal and storage complexes in the region is uneven;

$\checkmark$ decrease in the rate of replacement and renewal of fleet of the railway rolling stock;

$\checkmark$ length of the problem areas regarding the throughput capacity is about $30 \%$ of all regional railways;

$\checkmark$ significant backlog in the infrastructure and equipment of airports from the level of international civil aviation has led to a reduction in the volume of local air transportation;

$\checkmark$ growth of motorization has not yet led to a corresponding increase in the volume of construction and reconstruction of the road network; moreover, federal highways have practically peaked their capacity;

$\checkmark$ low technical level and unsatisfactory condition of the production base of the logistics infrastructure.

According to experts, the economy of the Krasnodar krai annually loses $3-4 \%$ of the gross regional product due to the underdeveloped transport and logistics infrastructure.

In these conditions, strategy for the development of transport and logistics infrastructure of the Krasnodar Territory should be based on an analysis of the current state and problems of waterborne and air transport, rail infrastructure, road and logistics networks. Apparently, it should comply with social and economic development goals of the region and economic tendency of Russia.

The problems of the development of the transport system of Russia, the transport and logistics complex of the regions, the use of public-private partnership mechanisms for the competitive growth of inland water transport in Russia, the development of the business environment for road construction in Russia, state regulation of investment and construction activities in the transport system were carried out by: E. Voskresenskaya, L. Vorona-Slivinskaya, T. Ponomareva [3], M. Mishlanova, G. Syzrantsev [4].

The issues of the work of transport companies in the context of sustainable growth of the region, the development of innovative projects based on the identification of competitiveness factors, the development of a competitive innovation project based on the analysis of internal and external factors, which would provide competitive advantages, were reflected in the works of such scientists as: R. Averbukh, G. Kononova, V. Tsyganova [5], E. Maslyukova, Y. Anoshina, A. Khakimova, M. Aleksandrovsky [6] and others.

The classification of various objects of the logistics infrastructure and the mechanism of functioning of the logistics centers in the transport system of Russia are considered in the works of V.D. Gerami [7], T.A. Prokofieva, V.I. Sergeeva [8].

Among foreign researches, there is a publication to be singled out by C.Yang, A. Taudes, A. Deng, L.Chen, F. Tian "Research on logistics parks: literature review and outlook". The authors overview the current state of research in the field of logistics parks and list promising research opportunities in this area [9].

Development of multimodal logistic centers, standard typology and hierarchy of those are considered in the study of C.D.Higgins, M.Ferguson, P.S. Kanaroglou [10].

The works that are devoted to the terminological aspect of studying various objects of the logistics infrastructure should not go without mention. Those were studied by M. Boile, S. Theofanis, A. Strauss-Wieder [11], M. Hesse [12], T. Notteboom, J.-P. Rodrigue [13], A.K. Nag, G.C. Gujar [14]. The authors note that at present there is no unified system of 
unambiguously interpreted terms and generally accepted classification to tell the type of an object of logistics infrastructure.

A comprehensive literature review was carried out in this study to achieve the set goal.

The goal of the study is to identify key problems and a strategy for the development of transport and logistics infrastructure of the Krasnodar krai.

The goal of the study predetermined the formulation and solution of the following interrelated tasks:

$\checkmark$ to determine the role of transport and logistics infrastructure in the socio-economic development of the Krasnodar krai;

$\checkmark$ to give a complete description of the transport and logistics modes of the region: waterborne and air transport, rail infrastructure, road and logistics networks;

$\checkmark$ to analyze the volume of passenger and cargo operations by waterborne (sea and inland), rail, road, passenger air transportation; to estimate the capacity of seaports, air transport infrastructure and logistics complexes;

$\checkmark$ to identify key problems in the development of transport and logistics infrastructure of the Krasnodar krai;

$\checkmark$ to set up a strategy for the development of the transport and logistics infrastructure of the Krasnodar krai on the basis of the study results.

\section{Materials and methods}

The scope of this study is to analyze the contemporary state of waterborne and air transport, rail infrastructure, road and logistics networks of the Krasnodar krai; determination of key problems that hinder the development of the main components of the transport and logistics infrastructure. The analysis is based on the officially confirmed macroeconomic parameters of social-economic development of the region.

The determinants that hinder the development of the waterborne and air transport, rail infrastructure, road and logistics network of the Krasnodar krai are estimated by observing and collecting factors which take place in the social-economic characteristics of the region. The results helped to set up a strategy for the development of the regional transport and logistics infrastructure.

The volume of passenger and cargo operations conducted by waterborne (sea and river), railroad, road and air transportation as well as the turnover capacity of the seaports, infrastructures of the air transport and logistics complex were analyzed with the use of comparative and statistical methods.

When setting up the strategy for the development of the transport and logistics infrastructure of the Krasnodar krai, the method of content analysis of electronic resources was used. The resources under study contained information on the organizational, economic and institutional mechanisms of the interaction of economic entities of the sea and air transport, rail infrastructure, road and logistics networks.

The transport and logistics infrastructure of the Krasnodar krai was chosen as the object of study.

The article used data from the Federal State Statistics Service of the Russian Federation, the Krasnodar krai and the Republic of Adygea, Krasnodar Transport Department of the Administration, legislative and regulatory acts, reference and analytical materials of the Ministry of Transport of the Russian Federation, the Ministry of Economic Development of Russia, web resources, information analysis content on organizational, economic and institutional mechanisms of interaction of business entities of waterborne and air transport, rail infrastructure, road and logistics networks. 


\section{Results and discussion}

The objects of transport and logistics infrastructure in the Krasnodar krai are of strategic importance not only for the development of the region, but also for the country as a whole. Transport and logistics infrastructure of the Krasnodar krai includes:

$\checkmark 9$ seaports with a cargo turnover of about 180 million tons per year. The ports of the Krasnodar krai bear about $30 \%$ of Russia's foreign trade cargo;

$\checkmark$ the railway trackage across the region is 2.2 thousand $\mathrm{km}$. (33\% of the total trackage in the Southern Federal District and $2.5 \%$ of Russia's);

$\checkmark$ federal international airports Krasnodar, Sochi, Anapa, as well as the regional airport of Gelendzhik. The airports of the Krasnodar krai pass 5\% of all passenger air transportation in Russia, whereas $4 \%$ of all departures are carried out from Sochi and Krasnodar airports. The total passenger traffic by air is more than 7.7 million passengers;

$\checkmark$ the road network of the region is more than 48 thousand $\mathrm{km}$ of federal, regional and local public roads, 2104632 units of automobile transport that carry over 420 million passengers a year and with a total cargo turnover of more than 4 billion tkm per year. [2]

The maritime transport network lies in the heart of the region's transport and logistics infrastructure, in particular port complexes with the direct access to international trade routes through the Azov and Black seas. The bulk of cargo is handled in the ports of Novorossiysk (67\%) and Tuapse (11\%).

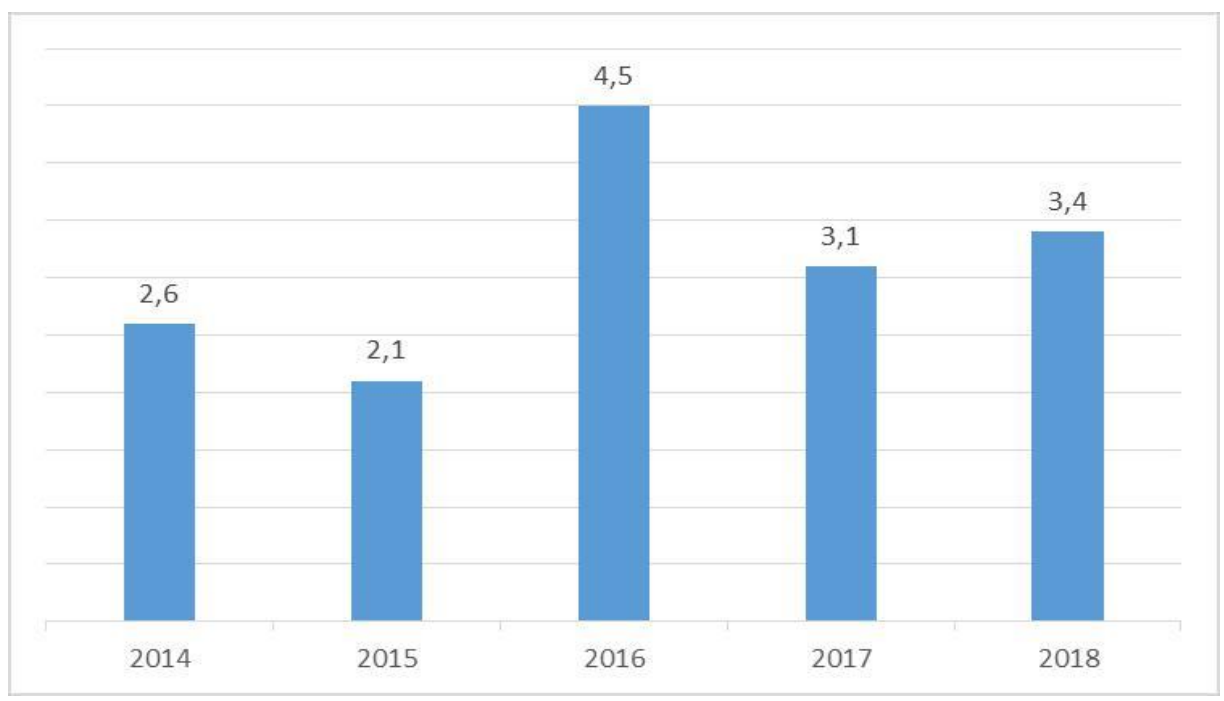

Fig. 1. Cargo carriage volume by waterborne (sea and inland) transport, million tons [2].

The seaport of Novorossiysk is the largest in Russia, with a cargo turnover of 117 million tons per year, where 85 million tons are bulk cargo and 32 million tons are dry cargo.

A grain terminal, a modern complex for transshipment of mineral fertilizers were put into operation at the port of Tuapse. Construction of the deep-sea oil terminal $1 \mathrm{~A}$ was completed.

In the area of the Cape Iron Horn, construction of a complex for oil and oil products transfer with a capacity of 6.5 million tons per year is underway.

A multimodal complex for transfer of oil, oil products and liquefied petroleum gases with a volume of 10.5 million tons is under construction in the Temryuk district.

Currently, the construction of new breakwater facilities and a berth front is being completed in Sochi, which will make it possible to accommodate cruise passenger ships 
with a length of more than $300 \mathrm{~m}$ and a capacity of up to 3100 people. On top of that, yachts and motor bonus could be also allowed to park.

In the Azov-Black Sea basin, sea passenger transportations are being restored. The Novorossiysk-Sochi line is served by three hydrofoils. 7 port points were put into operation to develop coastal maritime traffic in Sochi.

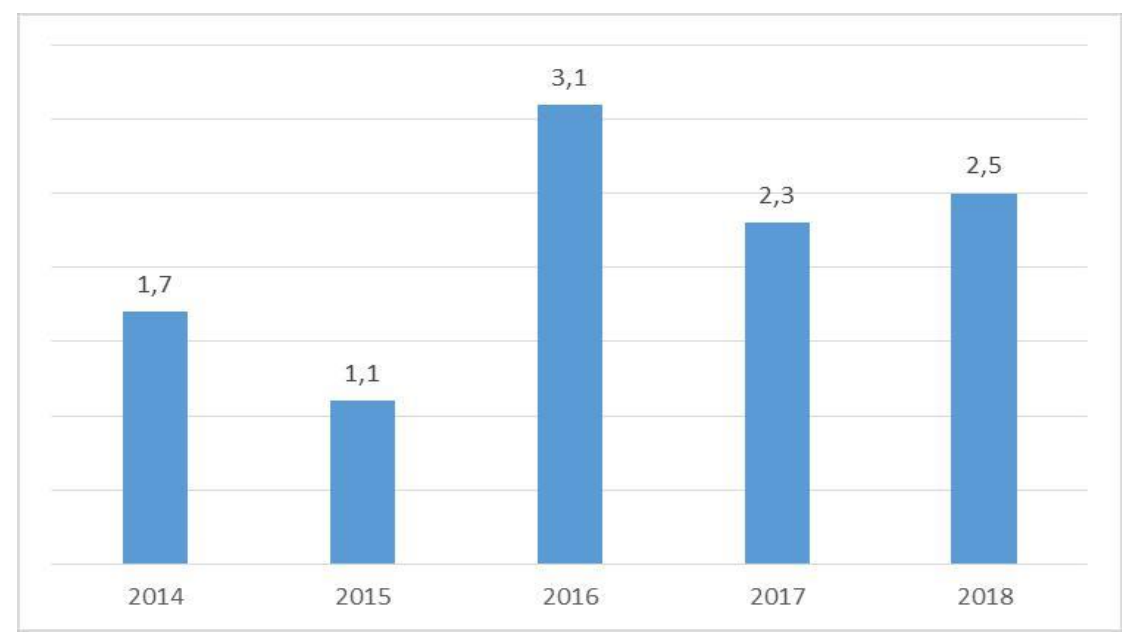

Fig. 2. Passengers transported by waterborne (sea and inland) transport, million people [2].

The main factor reducing the capacity of almost all Krasnodar seaports is the insufficient capacity of railway accessibility. At the same time, the railway companies accuse ports of long downtime of wagons and even entire trains (the problem of "abandoned trains"). In addition, the location of ports within the boundaries of the cities made it impossible to develop them further as building port infrastructure, reconstructing road and railways siding facilities, creating the required logistics centers.

The railway infrastructure of the Krasnodar krai is leading in terms of the trackage, freight carriage volume and passenger traffic among the constituent entities of the Southern Federal District.

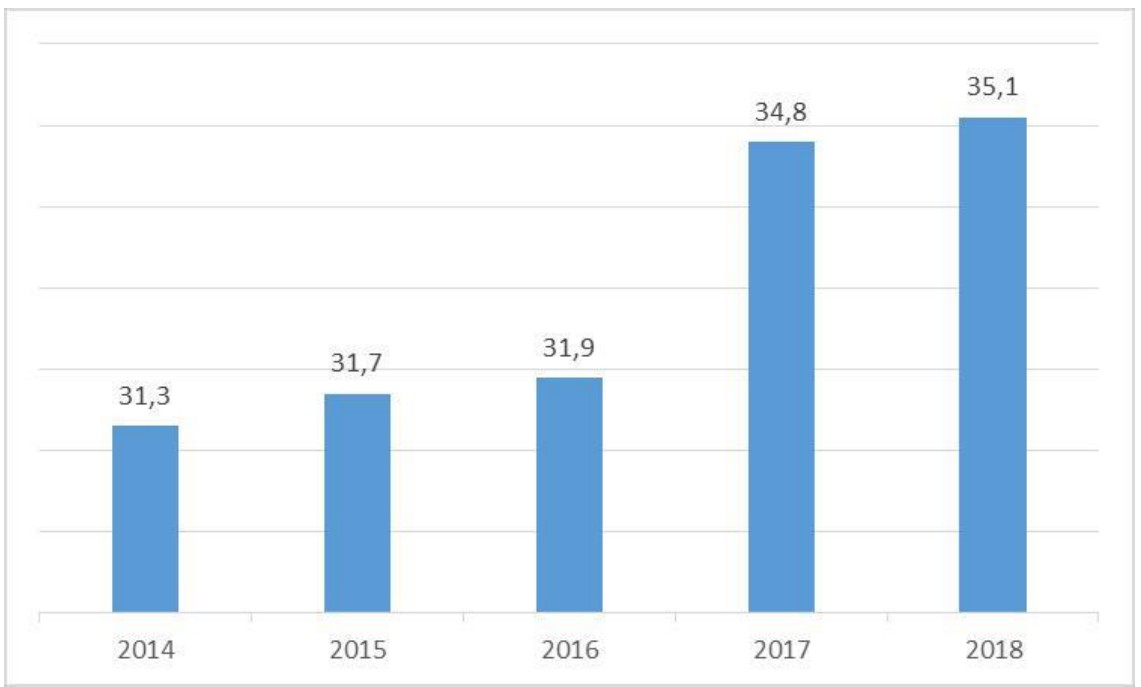

Fig. 3. Freight carriage volume by rail, million tons [2]. 
The railway trackage across the region is 2.2 thousand $\mathrm{km}$. (33\% of the total trackage in the Southern Federal District and 2.5\% of Russia's).

About $70 \%$ of all freight traffic across the region is carried out by rail and is organized by the companies of the North Caucasus Railway. The main junction stations of the North Caucasus Railway are: Tikhoretskaya, Kavkazskaya, Armavir, Krymskaya, Timashevskaya, Krasnodar, Belorechenskaya, Krivenkovskaya.

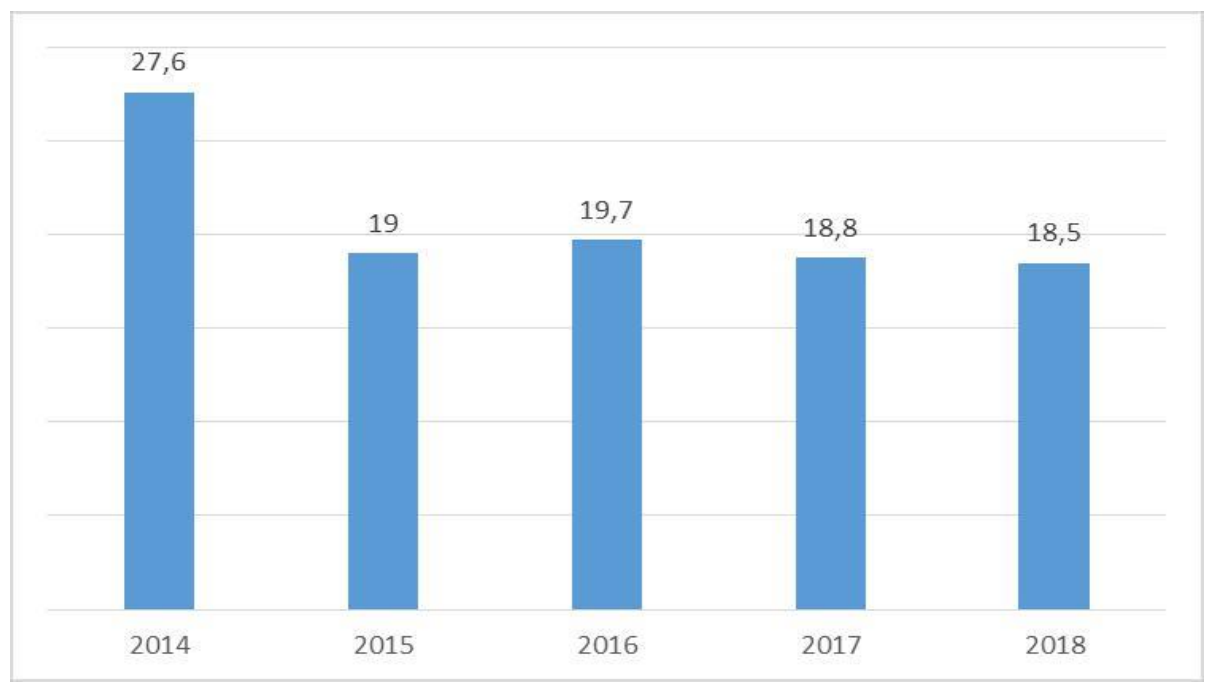

Fig. 4. Passengers transported by rail transport, million people [2].

The key problems identified in the infrastructure of railway transport are: firstly, the traffic flow is seasonal. During the holiday season, people mainly head to the resorts of the Azov-Black Sea coast from the European part of Russia, the Urals, Western and Eastern Siberia and the CIS countries. The major load falls at the stations of Krasnodar, Novorossiysk, Adler, Anapa and Tuapse. Such sections as Krasnodar -Novorossiysk Anapa, Tuapse - Adler are stretched to their throughput capacities.

Secondly, both during the harvest season and the following autumn-winter period, the railway transport infrastructure cannot provide timely supply of wagons with fuel and rolling stock for agricultural producers when sending agricultural products to the regions of Russia and for export.

The air transport infrastructure is represented by the airports of Krasnodar (Pashkovsky), Sochi (Adler), Anapa (Vityazevo), Gelendzhik, which are owned by the management company LLC Basel Aero.

The airports account for 7\% of all passenger air traffic in Russia (about 6.1 million people in 2018. About 40 Russian and foreign airlines operate flights to the Krasnodar krai on a regular and charter basis. The bulk of passenger and cargo transportation $(99 \%$ of the total volume of traffic in the region) is carried out by the international airports of Krasnodar, Sochi and Anapa.

Krasnodar Airport (Pashkovsky) is included in the list of airports of the national airfield system. The capacity of the Krasnodar airport is 700 passengers/hour, of the cargo terminal - $1000 \mathrm{~kg} /$ hour, where: 500 passengers/hour and $600 \mathrm{~kg} / \mathrm{h}$ of cargo is the capacity on domestic flights; 200 passengers/hour, cargo - $400 \mathrm{~kg} /$ hour is the capacity on international flights.

Sochi Airport (Adler) is included in the list of airports of the national airfield system. The capacity of the Sochi airport is 2500 passengers/hour, of the cargo terminal - 2000 
$\mathrm{kg} /$ hour, where: 1800 passengers/hour and $1100 \mathrm{~kg} / \mathrm{h}$ of cargo is the capacity on domestic flights; 700 passengers/hour, cargo - $900 \mathrm{~kg} /$ hour is the capacity on international flights.

Anapa Airport (Vityazevo) is a federal international airport, providing for the acceptance and release of aircraft in the first category according to the classification of the International Civil Aviation Organization. The airport operator is OAO "Aeroport Anapa" (OJSC Anapa Airport), owned by Basel Aero (a subsidiary of Basic Element company).

Up to day, there is one operating terminal at Anapa airport. In March 2016, the construction of a new terminal was launched. It will subsequently accept all domestic flights, and the old terminal after reconstruction will be primarily receiving international flights.

Gelendzhik airport is designed for comprehensive pre- and after-flight service for air travelers, as well as people who accompany and meet the passengers. The airfield capacity is 8 take-off and landing operations per hour. The airfield has an air-strip with a length of $3100 \mathrm{~m}$ and a width of $60 \mathrm{~m}$, capable of receiving aircraft of any types.

Despite the positive dynamics in the development of air transport infrastructure in the region, it is necessary to mention a significant backlog to implement the recommended by the International Civil Aviation Organization modern means and technologies in the field of air traffic management, automatic landing systems and other radio systems at the airports of Anapa (Vityazevo), Gelendzhik and Krasnodar (Pashkovsky).

The road transport network is the most important component of the production and social infrastructure of the Krasnodar krai. Transport communications unite all regions of the krai, which is a necessary condition for its territorial integrity, the unity of its economic space.

Road network of the region is one of largest in the country. It stretches for more than 48.4 thousand kilometers. The distance of the federal roads is $1420 \mathrm{~km}$, regional $-9054 \mathrm{~km}$ and local $-30605 \mathrm{~km}$.

As of January 1, 2018, the length of paved roads was $40,507 \mathrm{~km}$. (about $84 \%$ of all roads). [2]

There are 600 bridges and overpasses with a total length of $25398.50 \mathrm{rm}$ (running meter) on the road network of the region, of which: 27 overpasses over railways, 503 reinforced concrete bridge structures, 70 metal bridges. There are also two tunnel-type overpasses, 22 pedestrian crossings, 10,043 pipes with a total length of $157,362.87 \mathrm{rm}$. In addition, there are road maintenance facilities. Those are: auto-pavilions - 3248 pcs., bus stops - 4200 pcs., recreation areas and parking lots - 226 pcs., slip roads - 20108 pcs., reflective posts - 183374 pcs., traffic signs - 186677 pcs., guardrails - $1040.303 \mathrm{~km}$. In addition, there are sidewalks - $1168.738 \mathrm{~km}$, lighting - $500.229 \mathrm{~km}$, traffic lights - 57 pcs., weight control points - 13 pcs. [2]

Road density in the Krasnodar krai is currently 130 meters per $1 \mathrm{~km} 2$ (Russia's average is 70 meters per $1 \mathrm{~km} 2$ ). At the same time, the busiest directions of traffic are KrasnodarNovorossiysk, Dzhubga-Sochi, the Don and the Caucasus highways. 


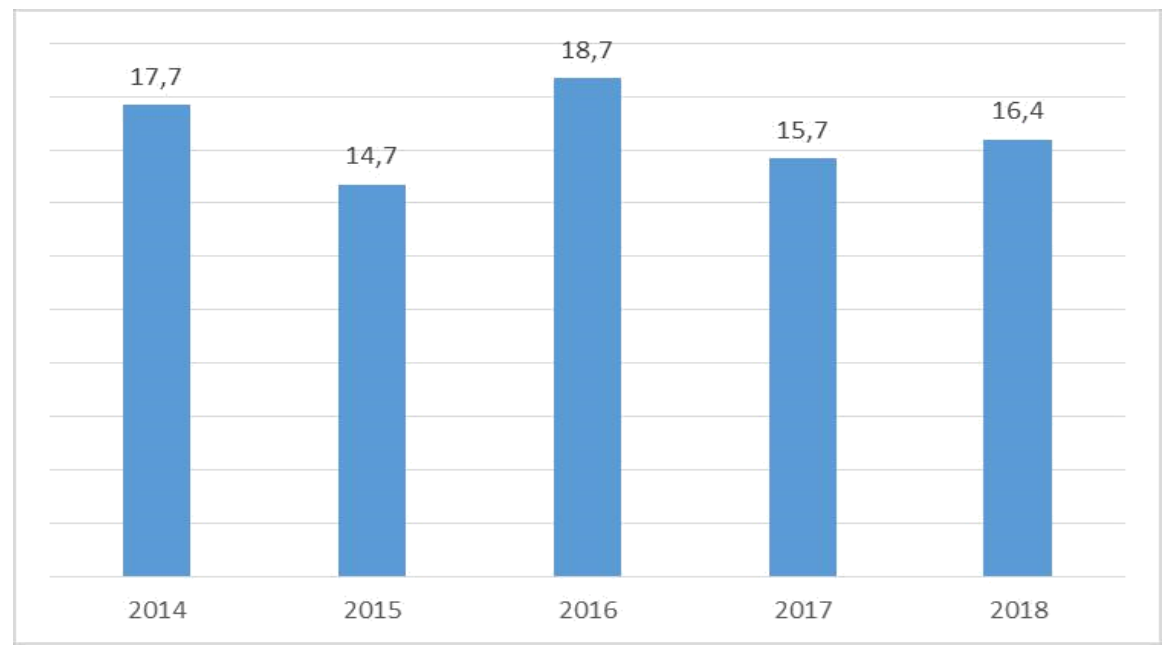

Fig. 5. Freight carriage volume by vehicles, million tons [2].

Passengers are transported on 92 inter-municipal suburban regular routes and on 219 inter-municipal long distance bus routes. However, due to the shortage and unsatisfactory condition of the vehicles, many city and long distance bus routes were closed, and the bus speed decreased. Modern urban public transport, including its high-speed modes, which could significantly reduce the severity of the problem of regional transport development, fails to get due attention.

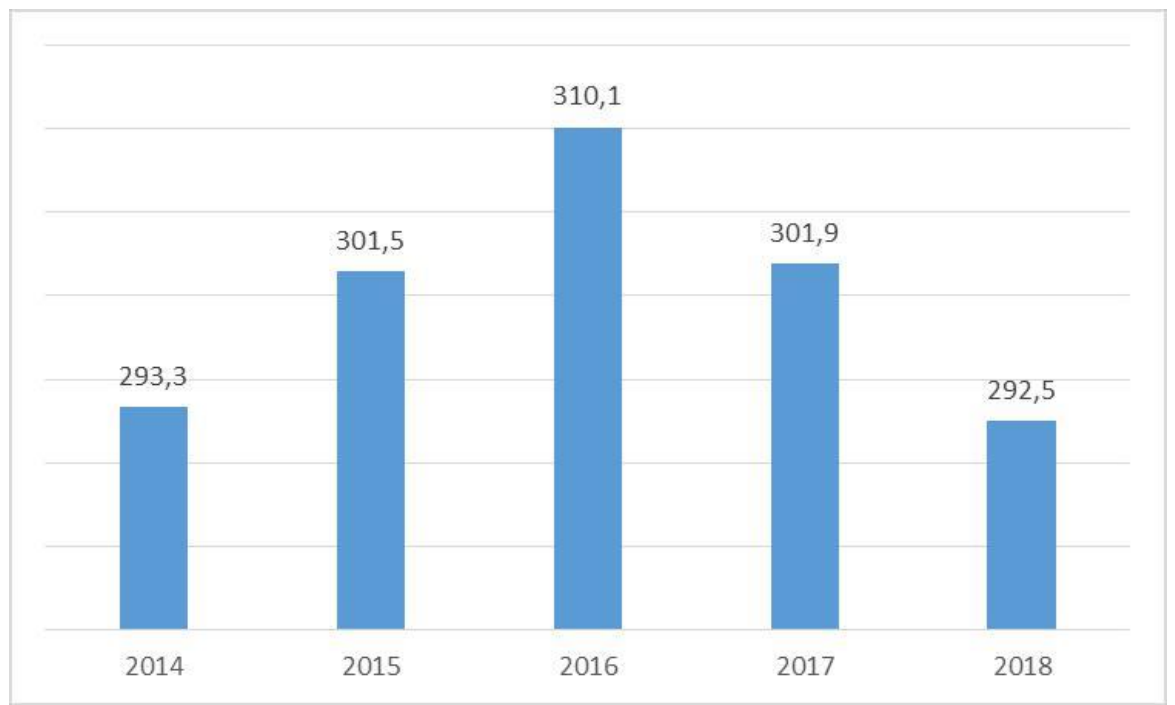

Fig. 6. Passengers driven by road (bus) transport, million people [2].

Therefore, the underdevelopment of the contemporary transport infrastructure, which reveals itself in the discrepancy between the level of development of roads and motorization and the demand for road transport, in a sharp reduction in the number of regional and local road (bus) routes, as well as in numerous bottlenecks at the certain types of transport.

The economy of the Krasnodar krai directly depends on the efficiency of the logistics infrastructure. Currently, the state of the logistics infrastructure is characterized by an 
increasing shortage of modern logistics centers, professional logistics operators and storage complexes of class A and B.

According to experts, in order to meet the ever-increasing demands of economic entities in the region, it is necessary to build at least 5 more logistics centers in Afipsky, Timashevsk, Taman, Armavir and Sochi. The construction of a new Maikop through road will give an alternative not only to transport companies, but also to logistics operators, who could reconsider the prospects of building a logistics center in Adygea. So, the shortage of logistics infrastructure in the territory of the Krasnodar krai may become a systemic constraint in the further investment development of not only the Krasnodar krai, but the Southern Federal District.

\section{Conclusion}

The analysis of the development of waterborne (sea and inland), rail, air, road transport and logistics network showed that despite significant positive trends in the work of the transport and logistics infrastructure of the Krasnodar krai, lots of problems are still unaddressed:

$\checkmark$ low throughput capacity of almost all seaports in the Krasnodar krai is due to insufficient throughput of railway sidings and the lack of port facilities focused on transfer of imported goods (containers and rolling cargo);

$\checkmark$ the regional rail infrastructure cannot cope with peak loads during the summer holiday season, it has not been modernized for a long time, a number of sites have no electricity. The current state of the railways does not only allow to increase transit potential, but even effectively meet the existing demand;

$\checkmark$ a significant backlog in the implementation of the recommended by the International Civil Aviation Organization modern means and technologies in the field of air traffic management, automatic landing systems and other radio systems was noted at the airports of Anapa (Vityazevo), Gelendzhik and Krasnodar (Pashkovsky);

$\checkmark$ road infrastructure does not cope with high loads during the summer holiday season. The low road density constrains the mobility of the population and has a negative impact on the environment. It is necessary to mention the unsatisfactory condition of road sidings to seaports, as well as the mismatch of their carrying capacity with peak loads;

$\checkmark$ the shortage of logistics infrastructure in the Krasnodar krai may become a systemic constraint in the further investment development of not only the Krasnodar krai, but the Southern Federal District.

Based on the study, a strategy for the development of the transport and logistics infrastructure of the Krasnodar krai is suggested:

$\checkmark$ creation of a logistics system that includes port terminals for various purposes, dry ports and simultaneous development of port and railway networks will increase the capacity of seaports and, therefore, their efficiency;

$\checkmark$ improving the infrastructure of waterborne (sea and inland) transport to ensure transport along international transport corridors, including the development of a water transport connection between the Azov-Black Sea and Caspian basins, will contribute to an increase in tourist flow and the development of tourism business in the region;

$\checkmark$ development of a set of measures to modernize the existing infrastructure, build additional main routes and electrify sections, upgrade rolling stock of passenger railway transport, taking into account modern requirements for comfort, safety and accessibility for people with limited mobility, will increase the capacity of the rail transport infrastructure and improve its efficiency;

$\checkmark$ the development of regional air transport system (including general aviation), airport infrastructure, and the balanced development of the entire air transport system of the region 
will contribute to the capacity growth and offer the passengers high-quality transport services;

$\checkmark$ the development of new traffic directions, which are part of the federal and regional routes, which will provide access to seaports, railway stations and road facilities, should unload large transport hubs and lead to a higher peak throughput capacity;

$\checkmark$ development of investment projects for the creation of transport and logistics terminals in the region, a simplified procedure of acquisition of land plots and a standard project of transport and logic centers will eliminate the deficit of logistics infrastructure in the Krasnodar krai.

\section{References}

1. Krasnodarskiy kray. Statisticheskiy yezhegodnik 2018 (Krasnodarstat, Krasnodar, 2019)

2. Krasnodarskiy kray v tsifrakh 2018 (Krasnodarstat, Krasnodar, 2019)

3. E. Voskresenskaya, L. Vorona-Slivinskaya, T. Ponomareva, MATEC Web of Conferences, TransSiberia 2018 239, 08009 (2018) https://doi.org/10.1051/matecconf /201823908009

4. M. Mishlanova, G. Syzrantsev, MATEC Web of Conferences, TransSiberia 2018 239, 08002 (2018) https://doi.org/10.1051/matecconf/201823908002

5. R. Averbukh, G. Kononova, V. Tsiganov, MATEC Web of Conferences, TransSiberia 2018 239, 08013 (2018) https://doi.org/10.1051/matecconf /201823908013

6. E. Maslyukova, Y. Anoshina, A. Khakimov, M. Aleksandrovskiy, MATEC Web of Conferences, TransSiberia 2018 239, 08012 (2018) https://doi.org/10.1051/matecconf 120182390801

7. V.D. Gerami, Logistika segodnya 1, 2-7 (2013)

8. T.A. Prokof yeva, V.I. Sergeyev, Logisticheskiye tsentry v transportnoy sisteme Rossii: Ucheb. posob. (Ekonomicheskaya gazeta, Moscow, 2012)

9. C. Yang, A. Taudes, A. Deng, L. Chen, F. Tian, Research on logistics parks: literature review and outlook. LISS 2013 (Springer Heidelberg, Berlin, 2015)

10. C.D. Higgins, M. Ferguson, P.S. Kanaroglou, Varieties of Logistics Centres: Developing a Standardized Typology and Hierarchy (2012) http:// docs.trb.org/prp/123874.pdf

11. M. Boile, S. Theofanis, A. Strauss-Wieder, Feasibility of Freight Villages in the NYMTC Region (2008) http://www.nymtc.org/project/freight planning/frtvillage/frtvillage_files/task_3_report

12. M. Hesse, Tijdschrift voor Economische 29 en Sociale Geografie 95(2), 162-173 (2004)

13. T. Notteboom, J.-P. Rodrigue, Transport and Communications Bulletin for Asia and the Pacific 78, 1-39 (2009) http://www.unescap.org/ttdw/Publications/TPTS_pubs/ bulletin 78/b78

14. A.K. Nag, G.C. Gujar, Transport Policy 16(5), 232-239 (2009) 